\title{
Émile Durkheim: de ideólogo da laicidade a precursor das teorias pós-seculares
}

Raquel Weiss'

\section{Resumo}

Este artigo apresenta e articula três eixos argumentativos que, em seu conjunto, propõem uma reinterpretação da concepção de religião presente na obra de Émile Durkheim, que resulta na possibilidade de tomar seus escritos finais como fonte de justificativa para teorias pós-seculares. O primeiro eixo insere o autor em seu contexto histórico, de modo a apresentar a natureza de seu engajamento normativo com o princípio da laicidade que compunha o ideário moral da Terceira República francesa. O segundo eixo constrói uma narrativa acerca da obra do autor na qual se indica uma transformação de sua concepção de religião, bem como da relação desta com a dimensão moral da vida. A tese aqui defendida é a de que seu entendimento sobre a religião presente em As Formas Elementares da Vida Religiosa (DURKHEIM, 1912) é plenamente compatível com as ideias de pós-secularização como diagnóstico de época e como horizonte normativo da modernidade tardia. O terceiro e último eixo representa uma tomada de posição por parte da autora acerca da ideia de pós-secular como melhor forma para ensejar o pluralismo religioso e axiológico.

Palavras-chave: Durkheim. Religião. Moral. Laicidade. Pós-secular. Pluralismo.

\section{Introdução}

Em nosso imaginário sociológico, Émile Durkheim tem sido quase sempre representado como teórico da laicidade, às vezes como crítico das religiôes reveladas e, em alguns casos, como defensor da substituiçáo funcional de Deus pela sociedade. Se a primeira dessas representaçôes está mais próxima de seu real engajamento com o universo político-filosófico de seu tempo e traduz com alguma fidelidade boa parte de seus escritos, o mesmo não ocorre com as outras duas, ainda que certas afirmaçóes, tomadas de forma isolada, possam conduzir a esta ideia.

\footnotetext{
Doutora em Filosofia pela USP. Professora do Departamento de Sociologia e do Programa de pós-graduação
} em Sociologia da UFRGS, Diretora do Centro Brasileiro de Estudos Durkheimianos. 
De um modo ou de outro, todas essas ideias têm como pano de fundo duas temáticas centrais em sua obra, que às vezes coincidem: a religião e a moral, esta tomada a partir de um recorte bastante específico, enquanto educação moral. Assim, minha proposta neste texto consiste em indicar uma série de articulaçóes possíveis, a partir da reconstrução de algumas dualidades que se apresentam ora como tensôes, ora como passagens, com o intuito de situar histórica e teoricamente o sentido específico da laicidade presente na obra durkheimiana. Com isso, espero salientar que este tema figura em seus escritos em uma conotação essencialmente normativa, que traduz o engajamento do autor com movimentos intelectuais e políticos de seu tempo, em relação aos quais se posiciona de forma singular.

Grosso modo, o percurso que constitui a primeira parte deste texto passa por uma brevíssima reconstrução histórica da temática da laicidade no âmbito da Terceira República e por uma apresentação do significado da ideia de educação moral laica defendida por Durkheim. Na segunda parte, sugiro uma ampliação interpretativa da obra do autor, defendendo que no decorrer de sua obra a radicalidade de suas convicções quanto à possibilidade de instituição de uma moralidade laica deu lugar a uma visão mais matizada e complexa acerca do significado da religiáo enquanto fenômeno social, que desloca a ênfase na dimensão da crença para a dimensão da práxis, isto é, dos ritos.

O desdobramento desse processo resulta na formulação de uma concepção geral sobre a modernidade que deixa em aberto o futuro das religiōes, indicando a possibilidade de um horizonte normativo de coexistência entre religiôes diversas, novas e antigas, sem abandonar imperativos seculares que reivindicam maior reflexividade e a necessidade de não submeter a sociedade política à autoridade de uma religiáo revelada. É precisamente nesse sentido que gostaria de sugerir que podemos tomar Durkheim como precursor das teorias pós-seculares. Ao final, convido a uma reflexão sobre a pertinência dessas teorias e as condiçóes de possibilidade do pós-secular como arcabouço moral para conceber a convivência entre diferentes crenças e práticas que habitam as sociedades contemporâneas, incluindo, aqui, as crenças e práticas estritamente seculares. 


\section{A Laicidade Francesa e a Ideia de Moralidade Laica}

O conceito de laicité encontra seu correspondente em português no termo laicidade, e é utilizado, grosso modo, para se referir à separaçáo entre estado e religião, ou para exprimir o caráter não religioso de qualquer instituição social. Trata-se de um modelo específico de secularização, no qual a tensão entre religião e mundo tomou a forma de uma separação formal entre igreja católica e instituiçôes públicas, subsumidas ao poder do Estado. No entanto, ainda que existam algumas convergências históricas entre os processos que se deram na França e em outros países que adotaram traduçóes do termo laicité, como é o caso de Brasil e Portugal, o entendimento sobre a posição de Durkheim a este respeito pressupóe que se considerem as especificidades de seu contexto.

O termo "laicidade" foi usado publicamente pela primeira vez na França em 1870, mas "[...] ainda que seja um neologismo recente, o conteúdo que o define se vincula a uma realidade muito mais antiga" (DE VAUCELLES, 1992). Dentre esses muitos fatores ligados às especificidades desse processo, podemos mencionar a história do Protestantismo na França, que disputou a hegemonia com o poder da Igreja Católica desde o início, sobretudo em relação ao ensino e à política. Em uma versão secular e racionalista, essa mesma disputa foi radicalizada no período da Revolução Francesa, na medida em que a derrubada da monarquia passava também por um ataque direto à instituiçáo que a legitimava. Além disso, dois outros importantes grupos do século XVII, os anabatistas e os espiritualistas, exerceram um papel importante na defesa da liberdade de consciência, elemento central na desconstrução da ideia de autoridade da igreja.

Portanto, a laicidade tem como pano de fundo a disputa com a hegemonia do poder católico e, em uma vertente mais radical, converte-se em doutrina que preconiza uma atitude de hostilidade em relação a todas as formas de religião. De modo geral, a história da laicidade na França pode ser dividida em dois eixos centrais, que também agrupam os diferentes debates acerca de seus princípios legitimadores e de seus processos de efetivação.

O primeiro deles é a disputa jurídico-política entre Estado e Igreja Católica, com diatribes que envolviam desde a posse de terras até o controle sobre diversas instituiçôes, como a educação. Essa tensão teve consequências 
importantes para o caráter mais incisivo dos debates que envolviam a separação entre estado e igreja. Por exemplo, no século XVII, a batalha pendeu para o lado da monarquia, e para que a igreja aceitasse a implementação de uma monarquia absoluta, ela recebeu o monopólio religioso, que significava, dentre outras coisas, o monopólio da educação, em particular da educação primária. A igreja católica tornou-se aliada da monarquia em todos os períodos de reação aos princípios da Revolução Francesa, isto é, durante a Restauração e o Segundo Império, combatendo os intentos republicanos, de modo que se converteu em um baluarte antidemocrático (DE VAUCELLES, 1992).

Esse foi um dos motivos pelos quais os pensadores de esquerda adotaram uma postura duramente antirreligiosa, visto que estava implicada a defesa de uma posiçáo política. Portanto, ao menos em seu início, a laicidade pode ser entendida como anticatolicismo, pressupondo engajamento consciente contra a igreja. Um primeiro momento importante desse processo, após a Revolução Francesa, foi a Concordata de 1801, assinada entre Napoleão Bonaparte e o papa Pio VII, que estabeleceu os termos do retorno do catolicismo como religião oficial da França, mas que já reconhecia a pluralidade de cultos - considerando legítimas algumas denominações protestantes - e que permitia algum grau de laicização da vida social. Apesar dos muitos debates que se seguiram na direção de um aprofundamento da laicização, inclusive com críticas duras ao catolicismo e a religiáo, foi somente em 1905 que a Concordata foi revogada do ponto de vista constitucional, com a promulgação da Lei de separação da igreja e do estado, que institui a garantia da liberdade de consciência e acaba com a subvenção do estado a toda e qualquer religião.

Como em todas as circunstâncias que envolviam o tema da laicidade, houve uma mobilização de diferentes grupos para debater essa lei, desde os defensores mais radicais da permanência do catolicismo como religião oficial até aqueles que lutavam por uma exclusão mais radical de qualquer forma de religião da esfera pública. Durkheim teve uma participação em um desses debates, organizado por um grupo mais moderado, que apostava na possibilidade de diálogo entre religiosos e livres-pensadores, que era parte das atividades dos colóquios da Abadia de Pontigny, organizados por Paul Desjardin. Nesse contexto, sua participação foi bastante discreta, a não ser em virtude de uma afirmação que provocou reaçóes fortes: a de que, do ponto de vista sociológico, a Igreja católica é uma monstruosidade (DURKHEIM, 1905, p. 369). 
Nesse posicionamento o que vemos é, sobretudo, uma constatação formal acerca do funcionamento da instituição, que teria uma deformação em virtude do apoio dado pelo estado. No entanto, náo encontramos neste pronunciamento, e nem em qualquer outro texto, nenhuma referência em defesa da exclusão da religião da esfera pública. Isso se explica pelo fato de que a temática da laicidade em Durkheim aparece apenas em um contexto bastante específico, em suas discussóes sobre a educação moral, que diz respeito ao segundo eixo importante da história da laicidade na França.

Desde muito tempo naquele país, a educação moral era ensinada durante a educação primária e esta era monopólio da igreja, de modo que o enfretamento com a religião católica passou também pela esfera da educação. Porém, aqui há um elemento ainda mais crucial, e que talvez seja o ponto central da peculiaridade do modelo de laicidade em relação aos processos de secularização ocorridos em outros contextos. Resumidamente, o pano de fundo desse processo foram os reiterados fracassos de implementação da república enquanto modelo político, que fez com que os intelectuais da Terceira República, que começou em 1870, debatessem seriamente a respeito do porque desses fracassos. O diagnóstico passava pela ideia de que não bastaria ter uma instituição republicana se não houvesse uma cultura republicana, o que somente seria possível com cidadáos imbuídos de um etos republicano, demandando uma reestruturação dos valores morais.

Conforme afirmam alguns autores, a França é um caso de país de religião autocrática que coexistia com um estado autocrático de modo que - segundo se entendia - a erosão da religião institucional tenderia a produzir uma erosão das próprias crenças, justificando um etos secular em detrimento da continuidade de um etos religioso. É nesse contexto que ganha sentido o termo morale laïque, “[...] que pertence propriamente à Terceira República francesa e se refere ao tipo de ética ensinada nas escolas" (STOCK-MORTON, 1988, p. 1).

Em suma, a análise da laicidade a partir da ideia de moralidade laica é o resultado do aprofundamento de uma discussão sobre o sentido do afastamento da igreja católica e do significado das reformas sociais que se desejava implementar. $\mathrm{O}$ pano de fundo é a ideia de que não somente um ataque formal à igreja católica mas também a diminuição de seu poder institucional não seriam suficientes para a construção de uma sociedade republicana, pois seria necessária uma transformação ao nível da consciência. 
Desde a época da Filosofia das Luzes, e mesmo antes disso, desenvolvia-se uma visão peculiar sobre o ser humano, que aos poucos se tornou referência para as instituiçóes públicas, articulada em torno da tese de que a emancipaçáo dos indivíduos e da sociedade depende do uso da razão crítica contra forças heterônomas e obscurantistas, que logo são identificadas com o catolicismo, tomado como instituição do passado. Em contrapartida há uma sacralização da escola, do progresso e da ciência, como instâncias capazes de lutar contra essas forças. Na época de formação de Durkheim, a principal oposição se dava entre conservadores e republicanos. E essa visão foi largamente abraçada por estes, "e o debate mais importante se dava no plano da educação" (FOURNIER, 2007, p. 43). Em 1879 os republicanos passaram a controlar câmara e senado, e nomearam como ministro Jules de Ferry - o mais radical defensor da educação moral laica.

Nesse momento, iniciou-se um longo e profundo processo de reforma no sistema de ensino, que começou com a Universidade, em 1884, tendo como tendo como referência o modelo alemão, com ênfase no ensino das ciências. É nesse quadro que Durkheim, ainda professor do Liceu, foi enviado em missão para a Alemanha, como parte de tal iniciativa do governo francês. Nesse período o jovem professor tomou contato com a estrutura do sistema universitário e com o trabalho dos moralistas alemáes, com destaque para as pesquisas de Wilhelm Wundt. No seu retorno o autor publicou dois artigos (DURKHEIM, 1887a, 1887b), os quais podem ser vistos como prenúncio das duas frentes de atuação perseguidas em sua carreira.

Em La Science Positive de la Morale en Allemagne, Durkheim realiza um balanço dos estudos científicos sobre a moral, estabelecendo os pontos de distanciamento em relação aos trabalhos realizados naquele país e o que viria a ser seu próprio programa de pesquisa. Trata-se, portanto, de um texto que diz respeito a seu projeto de fundaçấo de uma ciência dedicada a conhecer empiricamente o mundo social, que contemplaria o estudo de fenômenos centrais para a vida coletiva, como a moral e a religiáo. No outro artigo, La philosophie dans les universités allemandes, deparamo-nos com um segundo tipo de engajamento, de caráter propositivo, que no caso em questáo almejava oferecer subsídios para indicar reformas educacionais no nível superior.

É verdade que a atuação propositiva de Durkheim, isto é, que transcendia os propósitos de apenas explicar a realidade, contemplando a possibilidade 
de contribuir para transformá-la, deu-se em diversas frentes. Mas a principal delas, e que está diretamente ligada ao tema aqui tratado, diz respeito precisamente a seus escritos sobre a educação moral laica, que devem ser lidos como expressão da dimensão normativa de sua obra, que articula de forma bastante complexa os pressupostos ontológicos de sua sociologia e sua convicção quanto à necessidade de contribuir para a consolidação, alicerçada em sua posição ética de defesa dos direitos humanos e de valores democráticos (WEISS, 2011).

Conforme tive ocasiáo de discutir em outros textos (WEISS, 2007, 2009), a educação é o objeto que melhor permite elucidar essa relação entre positividade e normatividade na obra do autor, e é também o ponto de convergência de sua discussão entre religião, moral e laicidade. De forma genérica, podemos afirmar que as proposiçóes de Durkheim acerca da necessidade e da possibilidade da institucionalização de uma educação moral laica na escola primária representa a abertura de uma nova via em uma estrada pavimentada por diversos precursores, dentre os quais merecem destaquem Cousin, Quinet e Renouvier.

Victor Cousin fundou uma matriz filosófica que operou uma apropriação bastante curiosa do kantismo, misturando-a com elementos da filosofia escocesa, motivo pelo qual sua escola ficou conhecida como espiritualismo ou ecletismo. Cousin foi o filósofo mais influente durante a Segunda República, e até o começo do século XX os manuais escritos por ele ou por seus discípulos continuaram a servir de base para o ensino da educação moral nas escolas. $\mathrm{O}$ argumento central de seu sistema era o de que há uma base moral dentro de todos os indivíduos, e a religião seria apenas uma expressão disso, de modo que seria possível fundar uma moral racional que expressasse esses mesmos valores e sentimentos. A consequência deste projeto de laicidade era que ele apenas trocava um fundamento por outro, mantendo intactos os valores do passado, que eram valores essencialmente católicos. Por esta razão, e com o fracasso da Segunda República, em 1848 Cousin passou a ser questionado por seus próprios seguidores, perdendo força entre os defensores da República, ainda que sua influência real tenha perdurado ainda por muitos anos.

Edgard Quinet foi outra importante figura que lutou contra o Império e em defesa da educação laica. Em seu mais influente livro, L'Enseignement du 
Peuple, o autor afirmava que a educação era uma questão de direção moral, e por isso defendia que a República precisava de uma educação puramente laica. Segundo Stock-Morton (1988, p. 44), sua obra foi profética, “[...] principalmente na medida em que influenciou figuras proeminentes na reforma educacional da Terceira República - Jules Ferry, Jules Barni, Jules Steeg, Henri Marion, entre outros”. No entanto, Quinet não ofereceu qualquer base teórica nova além daquela de Cousin, mantendo o espiritualismo como forma secularizada de religiáo.

Charles Renouvier, por sua vez, pode ser considerado o filósofo mais influente da Terceira República, na medida em que derivou de sua teoria sobre a centralidade da liberdade uma fundamentação para justificar a necessidade moral da ação. Este autor mobilizou toda uma geração de cientistas e filósofos que viam seus trabalhos náo como uma busca pelo conhecimento isolada da realidade, mas como algo que deveria contribuir diretamente para a construção da República. Além disso, Renouvier redigiu o Manual dos Direitos do Homem e do Cidadão (RENOUVIER, 1848) que, ao contrário das doutrinas de Cousin, oferecia um novo fundamento para a moralidade cívica, compatível com os ideais humanistas da Revolução Francesa (LOGUE, 1993).

Deploige e Durkheim (1907) reconheceram publicamente o impacto de Renouvier em sua obra, que permeia desde sua concepção mais geral sobre a origem social das categorias do entendimento (JONES, 2001, 2006) até sua convicção acerca da finalidade prática da sociologia. Em relação a isso, é preciso destacar que sua contribuiçáo para as discussóes sobre a moralidade laica tem alguma referencia nas discussóes de Renouvier, especialmente em sua herança crítica e humanista, mas a desenvolve a partir de fundamentos completamente diversos, de raiz sociológica, e não orientado pelo propósito de ensinar valores específicos.

Algo que merece destaque nos escritos durkheimianos sobre o tema é o deslocamento que ele opera, de uma ênfase no conteúdo para uma ênfase na forma e no fundamento. No registro mais importante de seu pensamento sobre o assunto, os manuscritos de um curso com o título de A Educação Moral, publicados postumamente como livro, em 1925, Durkheim faz referência ao esforço de seus contemporâneos, e de muitos antes deles, em fundar uma moralidade em bases completamente novas. Para tanto, afirma Durkheim, é 
preciso descobrir o que é e o que tem sido a moral, não para continuar a ensinar os mesmos conteúdos, mas para entender a que função social ela corresponde, de modo a saber o que se espera nessa nova configuração social que se esperava construir. Além disso, segundo o autor, seria preciso que a nova educação oferecesse algo de novo em relação à moral anterior; senão, esse esforço não produziria qualquer resultado satisfatório ${ }^{2}$.

$\mathrm{O}$ ponto de partida de Durkheim era o de que a moral sempre existiu sob a égide das diferentes religióes, de modo que seria necessário examinar a moral religiosa para que se pudesse descobrir o que é a moral, enquanto fenômeno social para, depois disso, conceber o que a moralidade laica poderia acrescentar de novidade. A conclusão a que o autor chegou foi a de que a moral é um fato social constituído por dois elementos principais, quais sejam, o dever e o bem. $\mathrm{O}$ dever refere-se ao fato de que a moral exprime-se de modo imperativo, sob a forma de uma regra, na medida em que é uma orientação para a ação que deve ser seguida pelos indivíduos de forma obrigatória, delimitando a esfera do que deve e do que não deve ser feito. $\mathrm{O}$ bem diz respeito à desejabilidade da moral, na medida em que toda regra deve exprimir um ideal socialmente construído, que mobiliza os afetos dos indivíduos na direção de um horizonte compartilhado.

No caso da moralidade laica, esta deveria acrescentar um novo elemento, a racionalidade, que no registro durkheimiano não se refere à ideia de uma racionalidade imanente ao indivíduo, como expressão de uma Razão Prática Pura, tal como em Kant. Para o sociólogo francês a racionalidade da moral resultaria de sua transparência, isto é, do fato de que os indivíduos que aderem a ela precisam ter a consciência de sua origem social e da finalidade que está implicada nela, o que equivale a saber para que serve cada regra moral, a que ideal corresponde, e a clara noção sobre os processos envolvidos na criaçáo deste ideal.

Portanto, a educação moral laica para Durkheim consistiria não em um ensino de um conjunto de regras específicas, mas em formar na criança as disposiçóes necessárias para que se desenvolvesse enquanto um ser moral. Isto

2 A diferença da proposta durkheimiana em relação a seus precursores pode ser resumido em sua tese de que não bastaria que fosse oferecido o ensino laico da moral, mas seria preciso ensinar uma moral laica. 
significaria criar as condiçôes para desenvolver o espírito de disciplina - para garantir a capacidade de seguir alguma regra moral -, o espírito de adesão ao grupo para que a criança desenvolva prazer em compartilhar a vida com outras pessoas e identificar-se com os valores que representam o grupo - e, finalmente, o espírito de autonomia - que implicaria o conhecimento da origem social da moralidade, de modo que houvesse uma adesão com conhecimento de causa. Em relação ao conteúdo dessa moralidade, pouco ou nada é dito, a não ser sobre a importância do respeito à pessoa humana, ideal produzido durante a Revolução Francesa, e que deveria estar na base dos princípios republicanos ${ }^{3}$.

\section{Transformações na concepção de religião e a ideia de pós-secular}

Quanto a isso, gostaria de tecer duas consideraçóes importantes, que concernem diretamente à presente discussão acerca do sentido da laicidade na obra durkheimiana, ambas relacionadas com o argumento de que podemos aproximar o autor das teorias contemporâneas sobre a noção de pós-secular. A primeira delas é a inexistência de um discurso que demanda eliminação da religião da esfera pública, e a segunda é a ênfase na religião como crença, algo que é alterado na fase mais madura de sua obra.

Quanto à primeira consideração, trata-se de uma forma de interpretação baseada mais na constataçáo de uma ausência do que em afirmaçóes textuais diretas. No geral, as afirmaçôes de Durkheim são consideradas hostis à religião, sobretudo em virtude de argumentos como os que afirmam que Deus é a sociedade hipostasiada ou, ainda, que uma moralidade laica poderia servir melhor à sociedade contemporânea do que a moral religiosa. No entanto, nâo existe um enfrentamento combativo aos valores específicos de nenhuma religião, com a possível ressalva daqueles que fossem potencialmente contraditórios com o princípio da dignidade humana. Do mesmo modo, não há uma única frase do autor afirmando que as religiôes devem desaparecer ou tornar-se apenas uma questão privada.

3 O principal texto no qual encontramos referência explicita à sua defesa do ideal humano O Individualismo e os Intelectuais, publicado em 1898. Este texto é apresentado em edição crítica e bilíngue no primeiro volume da Biblioteca Durkheimiana (DURKHEIM, 20I6). Para compreender o sentido de seu "ideal humano", veja-se no mesmo volume os artigos de Jones, 2016; Watts Miller, 2016; Weiss, 2016. 
Tal ausência abre espaço para uma interpretação que indica que em Durkheim há uma visão com relação às religióes que difere substancialmente da laicidade mais combativa de muitos de seus contemporâneos, o que pode ser confirmado com enunciados mais diretos que se fazem presentes na fase final de sua carreira. Por ora, gostaria apenas de sugerir como possibilidade que a ideia de moralidade laica talvez pudesse ser articulada com as crenças religiosas, como algo que se superpóe a elas na medida em que demanda reflexividade acerca da razão de ser dos princípios norteadores da conduta. Isto pode conferir outro sentido à noção de moralidade laica que, sim, prescinde de qualquer divindade para existir, pois náo depende de qualquer religião revelada, mas que também não as exclui como condição necessária. Trata-se mais da possibilidade de fundar uma moralidade compartilhada que viabilize a coexistência de diferentes crenças em território comum, do que da imposição de uma moralidade que substitui crenças religiosas concretas.

A segunda questão está diretamente relacionada a um movimento interno da obra do autor, na qual encontramos diferentes concepçóes acerca do fenômeno religioso. Segundo Giovanni Paoletti (2012), há quatro questôes que pautam o debate sobre continuidade e ruptura na teoria sobre religiáo, quais sejam, a questão 1) da definição, 2) da metodologia, 3) da relação entre religião e 4) do futuro da religião. Dentre estas, as questóes 3 e 4 são diretamente relacionadas à sua posição sobre a laicidade, e a primeira está envolvida de forma indireta.

No início, a religião está fortemente associada à dimensão da crença, e o que define o religioso náo é o objeto da crença, mas a modalidade: é como se crê, e não no que se crê, e nesse momento, para Durkheim, "[...] a modalidade de crença que define a religiáo é a fé, isto é, toda crença que se aceita ou à qual se submete sem discussão" (1886a, p. 195). Essa noção está presente em suas liçốes sobre a Educação Moral, na medida em que a moralidade está umbilicalmente vinculada com a religiáo, como se a moral religiosa dependesse de uma crença religiosa, enquanto a moralidade laica pudesse ser baseada em uma crença racional, que não pressupóe a ideia de fé.

$\mathrm{Na}$ virada do século, Durkheim têm contato com as obras etnográficas de Spencer e Gillen, que exercem um profundo impacto na redefinição de sua concepção de religião (MILLER, 2012), fazendo com que ele perceba 
a importância dos ritos. É também nesse momento que apresenta pela primeira vez uma formulação mais complexa da noção de sagrado, enquanto expressáo dos momentos extraordinários produzidos pela vida coletiva (FILLOUX, 1990; MILLER, 2005; ROSATI, 2009; SHILLING; MELLOR, 1998; WEISS, 2012).

A partir desse momento, a noção de sagrado torna-se central na definição de religião, concebida como sistema de crenças e ritos relativos a coisas sagradas, que reúnem os indivíduos em torno de uma comunidade moral. $\mathrm{E}$, mais importante, o autor passa a considerar que o elemento mais importante da religião é sua dimensão prática, conferindo precedência dos ritos em detrimento das crenças. As crenças, poderíamos afirmar, são ideias sagradas que orientam os indivíduos em certa direção, mas o que é realmente essencial para a manutenção da vida coletiva é que a religião incita à ação, é sua virtude prática, como podemos ver claramente no texto abaixo, no qual Durkheim responde aos comentários feitos a seu livro recém-publicado, As Formas Elementares da Vida Religiosa:

Não poderia almejar aqui resumir o livro que recentemente publiquei. Porém, gostaria de pôr em relevo o argumento fundamental que permite preparar os espíritos a aceitar a explicação da religião que propus. Esse argumento refere-se ao caráter essencial da religião, todavia não imediatamente perceptível, precisamente porque ele é essencial. Ademais, essa questão não está no início do livro. Ela aparece progressivamente, à medida que o estudo avança e é, sobretudo, na conclusão que é posto à luz. Este caráter é o que se poderia chamar de virtude dinamogênica de toda espécie de religião. (DURKHEIM, 2012 [1913a], p. 21).

A principal consequência de tal deslocamento de ênfase da crença para os ritos é que a distinção entre moral laica e moral religiosa fica mais opaca, na medida em que a moral também deve incitar à ação. Além disso, a própria noção de moral compartilha um elemento que é definidor da noção de religiáo, qual seja, o sagrado, na medida em que o ideal passa a ser considerado o núcleo da moral e este, por sua vez, é definido como conjunto de ideias sagradas. Há, sem dúvida, uma tentativa de separar a ideia de religiáo das demais esferas da vida, o que inclui também a moral. Porém, este é um problema para o qual Durkheim parece não conseguir encontrar uma saída óbvia. Vejamos.

A criação e a reprodução das crenças - sejam elas religiosas stricto senso, ou apenas crenças morais - pressupóe momentos de efervescência, para que 
certas ideias possam ser consagradas; do mesmo modo, precisam de ritos, para que possam ser renovadas e tenham continuidade ao longo do tempo. Para que os ritos existam, é preciso que sejam práticas respeitadas e sacralizadas no âmbito de determinada comunidade. Portanto, ou assumimos que toda comunidade moral é, também ela, um tipo de religião, mesmo que não exista a figura de uma divindade, ou não se pode conceber a possibilidade de crenças e valores puramente seculares.

Mesmo que se aceite essa concepção mais ampla de religião, isso coloca um problema prático para o modelo de educação moral de Durkheim, na medida em que a noção de racionalidade demandaria articulação com a noção de crença. Do mesmo modo, seria preciso conceber rituais capazes de vincular a sociedade como um todo em torno de valores tais como autonomia da consciência e respeito à pessoa humana, na medida em que a validade da moral não depende apenas de sua coerência lógica, mas pressupóe também adesão afetiva. Por essa razão, as transformaçóes não podem ser dar apenas no domínio da crença.

Portanto, isso significa a necessidade de redefinir também o significado da ideia de moralidade laica nesse contexto de compreensão acerca do papel do sagrado e da importância dos ritos, que oferece uma nova compreensão ao fenômeno religioso. Como último passo, proponho que essa transição permite apresentar Durkheim menos como um defensor de uma laicidade de combate (POULAT, 2003) e mais como propositor de uma laicidade moderada, mais condizente com teorias contemporâneas que defendem a coexistência entre religióes múltiplas e instituiçóes seculares (ROSATI; WEISS, 2015), e que tem na ideia de pós-secular um de seus desdobramentos mais importantes (ROSATI, 2009, 2015).

O conceito de pós-secular foi inicialmente cunhado por Habermas (2008, 2010) no contexto de um debate com o então cardeal Ratzinger, que buscava exprimir uma visão sobre a sociedade moderna na qual as pessoas, sejam elas seculares ou religiosas, estão diante de uma circunstância que as convida a uma constante autorreflexão, a partir da percepção da existência de modos de vida distintos. Isso introduziria a possibilidade de uma aprendizagem complementar, que pressupóe que a diferença náo seja tomada como elemento a ser combatido, mas como um convite para examinar os pressupostos que 
norteiam a própria vida. As formulaçôes aqui apresentadas seguem a interpretação geral proposta por Rosati $(2014,2015)$ e são complementadas por alguns argumentos de Stoeckl e Rosati (2013) que oferecem um aprofundamento das noçóes gerais formuladas por Habermas no quadro geral de uma sociologia da religiáo.

Grosso modo, podemos falar de um duplo registro: o pós-secular enquanto princípio normativo que define um posicionamento acerca das condiçóes ideais de coexistência entre religióes e instituiçôes seculares, e de um registro histórico e sociológico, na medida em que descreveria um processo da modernidade tardia, em que as religióes disputam a permanência na esfera pública, recusando o veredito de autores do início da modernidade, que as relegaram à esfera privada. Segundo Rosati (2015), o que é próprio de uma sociedade pós-secular são as seguintes características.

Primeiramente, a coexistência entre visōes de mundo e práticas seculares e religiosas; em segundo lugar, uma reflexividade entre visóes de mundo seculares e tradiçóes religiosas; em terceiro lugar a desprivatização, com a possibilidade de que as religióes façam parte da vida pública; em quarto lugar, a presença de condiçóes para a existência de um pluralismo religioso em vez de um simples monopólio religioso; e, finalmente, formas transcendentes e imanentes do sagrado.

Em outros termos, o que a ideia de pós-secular implica uma atitude reflexiva em relação à noção de secularização; longe de significar uma condição de dessecularização (BERGER, 2001) - uma situação que se dá após a secularizaçáo - ela indica uma nova consciência por parte das sociedades contemporâneas a respeito da coexistência de formas de vida seculares e religiosas, indicando um modo de ser plenamente religiosos e plenamente modernos.

Sob um ponto de vista empírico, essas consideraçóes exigem que instituições seculares e moralidades modernas assumam uma atitude menos arrogante em relaçáo àqueles grupos e indivíduos que não desejam se tornar seculares, autônomos ou autênticos. Sob uma perspectiva mais prática, podemos apontar duas fontes possíveis - a secular e a religiosa - para a tolerância, compreendida como o máximo postulado sagrado necessário ao estabelecimento de uma sociedade pós-secular (ROSATI; WEISS, 2015). Aceitando-se esta dupla fonte, elas podem relacionar-se em um processo de aprendizagem 
complementar. Isso equivale a afirmar que há outras fontes modernas para valores como a tolerância e o respeito mútuo que não apenas aquelas centradas em filosofias de matriz liberal.

Isso significa reconhecer que certos valores essencialmente modernos também são uma crença, que demandam adesão e renovação das convicçóes. Exemplo de processos de aprendizagem pós-secular é o que podemos chamar de "virada pós-secular" nas teorias feministas, como aparece de forma bastante interessante nos trabalhos de Rosi Braidotti (2008), que salienta a necessidade de tomar em consideração a contribuição oriunda de diferentes religiôes para o desenvolvimento de perspectivas emancipatórias envolvendo questôes de gênero.

Voltemos a Durkheim, para tentar articular esses elementos e destacar de que modo sua teoria nos ajuda, primeiramente, a traçar um quadro coerente do mundo contemporâneo e, depois, como podemos encontrar em seus escritos algumas pistas para pensar sobre as condiçóes de possibilidade de existência efetiva de uma sociedade pós-secular.

Podemos caracterizar o momento presente como uma época de intenso pluralismo, seja ele religioso stricto senso, étnico, político, cultural etc. Se na sociedade em nível macro temos um mínimo de coesão garantido de forma "orgânica” (DURKHEIM, 1902), temos, no seio dessas macrossociedades, inúmeras microcomunidades (tribos urbanas, movimentos sociais, grupos secundários etc.) que conferem identidade particular a seus membros, promovendo um tipo de solidariedade muito semelhante ao da solidariedade mecânica das sociedades tradicionais. Semelhante, mas náo igual, na medida em que os indivíduos que a elas aderem vivem em um mundo em que é possível aderir a mais de um tipo de comunidade, e sua participação em mais de um tipo de grupo identitário dependerá de quão totalitária for sua adesão ao microgrupo específico.

E por que acontece esse fenômeno? Por que nossa sociedade contemporânea engendrou um novo tipo de vida social, no qual solidariedade orgânica e mecânica parecem coexistir? De certo modo, essas microcomunidades promovem situaçôes de efervescência no interior da mesma macrossociedade, produzindo percepçóes variadas sobre sagrados diversos. A energia experienciada nessas circunstâncias faz com que a participação em grupos secundários se torne cada vez mais atraente para os indivíduos. Logo, vemos no papel da 
efervescência uma das explicaçóes possíveis para o pluralismo religioso, para os diversos movimentos de renovação ou mesmo para movimentos não religiosos stricto senso, como movimentos de contestação, de intervençáo urbana, de crítica social etc.

Ainda como parte desse movimento, um fenômeno que pode vir a ocorrer é que tudo o que não faz parte da vida desse grupo passar a ser identificado com o profano, e o que é de dentro, com o sagrado, podendo gerar situaçóes de tensão social. Nas sociedades contemporâneas tem havido uma transformação no papel desempenhado pela efervescência. E, ao mesmo tempo em que ela pode favorecer a intensificação da vida coletiva nos microgrupos, ela pode fazer com que a vida que se passa na macrossociedade comece a perder importância, diluindo gradativamente o caráter sagrado de valores estruturantes das sociedades contemporâneas, como o respeito à pessoa humana e à liberdade individual. Afinal, são poucos os momentos de efervescência em escala nacional e global, se forem comparados aos que ocorrem nos microgrupos.

Portanto, nesse momento talvez o pós-secular não corresponda a um diagnóstico de época preciso, e permaneça mais como um horizonte norteador da ação. Na obra de Durkheim, encontramos uma "sugestão operacional" acerca das condiçôes necessárias para que uma sociedade pós-secular possa ser efetiva evitando degenerar em uma situaçáo de confronto insolúvel entre sagrados divergentes. O ponto central passa pela consciência dos diversos grupos e instituiçôes comprometidos com esse princípio quanto à necessidade de produçáo e renovação da fé em um sagrado compartilhado [máximo postulado sagrado] que possa ser fundamentado a partir dos princípios internos de cada religião [mesmo no sentido lato], que se coloca sob a forma do princípio de respeito mútuo, convivência e tolerância.

Essa noção pode ser desenvolvida a partir do texto $O$ Individualismo e os intelectuais (DURKHEIM, [1898b] 2016), no qual o autor se refere ao respeito à pessoa humana não como direito natural, mas como artigo de fé, um valor socialmente construído, único compatível com as sociedades contemporâneas e que poderia articular subjetividades distintas.

No momento em que o autor redigiu o texto, muito possivelmente a sua ideia era a de que o ideal humano deveria substituir outras formas de crença, mas com o desenvolvimento de sua concepção sobre a religiáo e a 
moral, talvez tenha percebido sua insuficiência para produzir uma consciência moral complexa, que contempla também a dimensão afetiva, bem como carecia de dispositivos de cultivo do sentimento de pertencimento ao grupo. Nesse sentido, na transição efetuada por Durkheim de 1902 a 1912, há uma compreensão da complexidade do papel desenvolvido pelas religióes, e a constatação de que as crenças precisam ser renovadas por práticas (ritos) em escala que permita o engajamento real dos indivíduos. E essas práticas e crenças não podem ser imposiçôes artificiais; devem brotar da "vida verdadeira", enraizadas na vida em comunidade, algo que historicamente foi proporcionado pelas religióes tradicionais.

No entanto, a diferença do cenário contemporâneo, ao menos nas sociedades ocidentais, e que pode ser entendido como secularização stricto senso, é que não há mais a imposição de uma religiáo oficial. Isso abre espaço para a pluralidade da criatividade humana, para que esta tenha maiores condiçóes de se expressar, engendrando múltiplas formas possíveis de religião, que podem tanto reproduzir as crenças das religióes tradicionais quanto produzir crenças completamente novas, pressupondo ou não a existência de uma realidade extramundana. Aqui podemos incluir grupos muito diversos e não tradicionalmente identificados com religião, por exemplo, movimentos ecológicos e grupos que lutam por direitos de grupos historicamente discriminados, como os movimentos LGBTT, grupos de defesa de direitos humanos etc.

Afinal, do ponto de vista durkheimiano, o que é essencial no fenômeno religioso é sua existência enquanto comunidade moral que se articula em torno do compartilhamento de ideias sagradas, as crenças, e de práticas sagradas, os ritos. Portanto, é a existência do sagrado e das condiçóes para sua produção que é central para se conceber a dinâmica da vida religiosa.

Diante dessas consideraçóes, aquele ideal, formulado em seus textos a partir de 1898, pode ser pensado apenas como condição formal da existência de um mundo pós-secular, cujo conteúdo é dado pela interação específica entre diferentes sagrados em contextos variados. Como menciona o autor,

Virá o dia em que nossas sociedades conhecerão de novo momentos de efervescência criadora ao longo das quais novos ideais surgirão, novas fórmulas aparecerão para servir, durante um tempo, de guia à humanidade; e, uma vez vividos esses momentos, os homens sentirão espontaneamente a necessidade de revivê-las de tempos em tempos pelo 
pensamento, isto é, de conservar sua lembrança por meio de festas que renovem regularmente seus frutos. (DURKHEIM, 1912, p. 611).

Em vez de encerrar com um diagnóstico sobre o futuro, ou com uma tomada de posição, gostaria de concluir propondo uma reflexão sobre quais valores desejamos e podemos desejar ter em comum, e o que precisamos fazer para que essa multiplicidade de sagrados possam continuar a existir, sem que a existência de alguns represente uma ameaça ao direito de existir dos sagrados dos demais indivíduos ou grupos. Ou seja, se vivemos em uma sociedade plural, e gostamos de que ela assim o seja, o desafio é pensar as condiçóes de possibilidade de sua continuidade no futuro. Não podemos prever quais serão os novos ideais, mas podemos parar para pensar sobre o significado dos ideais que temos agora.

\section{Referências}

BERGER, P. A Dessecularização do mundo: uma visão global. Religiáo e Sociedade, v. 21, n. 1, p. 9-23, 2001.

BRAIDOTTI, R. Spite of the Times The Postsecular Turn in Feminism. Theory, Culture \& Society, v. 25, n. 6, p. 1-24, 1 nov. 2008.

DE VAUCELLES, L. Laïcité en débat. Archives des sciences sociales des religions, v. 78, n. 1, p. 179-190, 1992.

DURKHEIM, É. A propos du conflit de la morale et de la sociologie. Lettres de M. Durkheim et réponses de S. Deploige. Revue néo-scolastique, v. 14, n. 56, p. 606-621, 1907.

DURKHEIM, É. La philosophie dans les universités allemandes. Revue internationale de l'enseignement, v. 13, p. 313-440, 1887a.

. La Science Positive de la Morale en Allemagne. Revue philosophique, 1887c Reproduzido em Textes 2, v. 24, p. 24, p. 33-58, p. 113-42, p. 275-284, 1887 b.

L'Individualisme et les Intellectuels. Revue Bleue, v. 10e tome, p. 7-13, 1898.

De la Division du travail social. 2. ed. Paris: Alcan, 1902.

. Sur la Séparation des Églises et de l'état [contribuição à discussão]. Libres Entretiens de L'Union pour la Vérité, v. 1, p. 369-371, p. 496-500, 1905.

A propos du conflit de la morale et de la sociologie. Lettres de $\mathrm{M}$. Durkheim et réponses de S. Deploige. Revue néo-scolastique, v. 14, n. 56, p. 606-621, 1907. 
. Les Formes Élementaires de la Vie Réligieuse. Paris, Félix Alcan, 1912.

. O problema religioso e a dualidade da natureza humana. Debates do NER, v. 1, n. 22, p. 27-62, 21 dez. 2012.

. O Individualismo e os Intelectuais. In: CONSOLIM, M.; OLIVEIRA, M.; WEISS, R.

Biblioteca Durkheimiana Vol. 1 - O Individualismo e os Intelectuais, de É. Durkheim. São Paulo: Edusp, 2016, p.38-65.

FILLOUX, J-C. Personne et sacré chez Durkheim/The Individual and the Sacred in Durkheim. Archives des sciences sociales des religions, v. 69, n. 1, p. 41-53, 1990.

FOURNIER, M. Émile Durkheim (1858-1917). Paris: Fayard, 2007.

HABERMAS, J. Notes on Post-Secular Society. New Perspectives Quarterly, v. 25, n. 4, p. 17-29, 1 set. 2008.

_. An Awareness of What is Missing: Faith and Reason in a Post-secular Age. [S.1.]: Polity, 2010 .

JONES, S. S. Durkheim reconsidered. Cambridge: Polity, 2001.

. Action and the question of the categories: a critique of Rawls. Durkheim Studies, v. 12, p. 37-66, 2006.

O Individualismo. In: CONSOLIM, M.; OLIVEIRA, M.; WEISS, R.. Biblioteca Durkheimiana Vol. 1 - O Individualismo e os Intelectuais, de É. Durkheim. São Paulo: Edusp, 2016. p. 85-94.

LOGUE, W. Charles Renouvier, Philosopher of Liberty. Louisian: Lousiana State University Press, 1993.

MILLER, W. W. Dynamogénique and Élementaire. Durkheim Studies, v. 11, p. 18-32, 2005.

. A Durkheimian Quest: Solidarity and the Sacred. New York; Oxford: Berghahn Books, 2012.

"O Individualismo e os Intelectuais" de Durkheim. In: CONSOLIM, M.; OLIVEIRA, M.; WEISS, R. Biblioteca Durkheimiana Vol. 1 - O Individualismo e os Intelectuais, de É. Durkheim. São Paulo: Edusp, 2016. p. 107-121.

PAOLETTI, G. Les deux tournants, ou la religion dans l'Oeuvre de Durkheim avant Les formes élémentaires. L`Année Sociologique, Vol. 62, 2012/02, p. 289-311. 
POULAT, É. Notre laïcité publique. Paris, Berg International Éditeurs, 2003.

RENOUVIER, C. Manuel Républicain de L'Homme et du Citoyen. Paris: Pagnerre, 1848. (v. Premiére).

ROSATI, M. Ritual and the sacred: a neo-Durkheimian analysis of politics, religion and the self. Farnham: Ashgate, 2009.

Contingenza, creatività, auto-trascendenza: religione e secolarizzazione in Hans Joas

| Reset. Reset. 2014. [S.1: s.n.]. Disponível em: <http://www.reset.it/blog/contingenza-creativitaauto-trascendenza-religione-e-secolarizzazione-in-hans-joas>. Acesso em: 16 mar. 2015.

The Making of a Postsecular Society: A Durkheimian Approach to Memory, Pluralism and Religion in Turkey. [S.1.]: Ashgate Publishing, Ltda., 2015.

; WEISS, R. Tradição e autenticidade em um mundo pós-convencional: uma leitura durkheimiana. Sociologias, v. 17, n. 39, p. 110-159, ago. 2015.

SHILliNG, C.; MELLOR, P. A. Durkheim, Morality and Modernity: Collective Effervescence, Homo Duplex and the Sources of Moral Action. The British Journal of Sociology, v. 49, n. 2, p. 193-209, jun. 1998.

STOCK-MORTON, P. Moral Education for a Secular Society. New York: State University of New York Press, 1988.

STOECKL, K.; ROSATI, M. Multiple Modernities and Postsecular Societies. [S.I.]: Ashgate Publishing Ltda., 2013.

WEISS, R. Apresentação: O Ensino da Moral na Escola Primária. Novos Estudos Cebrap, v. 78, p. 59-61, 2007.

A Concepção de Educação de Émile Durkheim como Chave para a Passagem e Entre Positivo e Normativo. In: MASSELLA, A et al. (Org.). Durkheim 150 Anos. 2009. p. 169-189.

Émile Durkheim e a Fundamentaçáo Social da Moralidade. 2011. 280 f. Tese (Doutorado em Filosofia) - Programa de Pós-Graduação em Filosofia, Universidade Federal de São Paulo, São Paulo, 2011.

. From Ideas to Ideals: effervescence as the key to understanding morality. Durkheim Studies, v. 18, p. 81-97, 2012.

. Durkhiem, um "Intelectual" em defesa do "Ideal Humano". In: CONSOLIM, M.; OLIVEIRA, M.; WEISS, R. Biblioteca Durkheimiana Vol. 1 - O Individualismo e os Intelectuais, de É. Durkheim. São Paulo: Edusp, 2016. p. 95-106. 


\section{Émile Durkheim: from secular ideologist to forerunner of post- secular theories}

\section{Abstract}

This paper presents and articulates three points that, taken together, suggest a reinterpretations of Durkheim's concept of religion, allowing us to take the arguments of his late writings as a key ground to postsecular theories. The first point inserts the author in his historical environments, highlighting his commitment to the principle of laicité, part of the moral ideals of the Third Republic. The second point builds a narrative where the idea religion and its relationship with morality undergoes a transformation along his career. The thesis is that in The Elemental Forms of Religious Life (DURKHEIM, 1912) he presents a concept of religion fully compatible with the idea of post-secularization both as a diagnostic of the present times and as a normative horizon for late modernity. In the third and last point I take a stand in defending the idea of postsecular as the best way to encourage religious and axiological pluralism.

Keywords: Durkheim. Religion. Morality. Secularism. Postsecular. Pluralism.

Recebido em: 21/02/2017.

Aprovado em: 19/04/2017. 